\title{
Analysis of the speech act of request in the foreign language classroom
}

\section{Katrin Herget, Noemí Pérez}

Department of Languages and Cultures, University of Aveiro, Portugal.

\begin{abstract}
Nowadays, teaching languages for specific purposes, in particular in the field of entrepreneurship, has to focus on pragmatic and intercultural aspects in response to a multicultural professional reality that comprises different areas of knowledge. Our study aims at analyzing the speech act of making a request in German and Spanish by Portuguese native speakers, i.e. BA students of Languages and Business Relations at University of Aveiro. For this study, two different types of tests were performed: the Discourse Completion Task (DCT) and the Rating Assessment Test. The data provided by the answers given to these two surveys will help the teacher to understand the pragmatic difficulties students have when making a request in these two foreign languages. The information obtained will help the teacher to focus on aspects that are really problematic from the pragmatic point of view, and at the same time, to find and implement strategies and activities that help students improve their pragmatic awareness and overcome difficulties that may arise in intercultural communication. Hence, the objective is to contribute to an adequate development of the students' pragmatic and intercultural communicative competence.
\end{abstract}

Keywords: intercultural pragmatics; intercultural communicative competence; speech act; teaching; foreign languages. 


\section{Introduction}

Since the last decades of the last century intercultural pragmatics has attracted the interest of many experts and professionals in teaching, especially in the area of languages for specific purposes such as Business Studies and Economics, where a misinterpretation of a gesture or a word can cause misunderstandings or problems in international trade relations. This study, therefore, falls within the area of intercultural pragmatics, whose relevance to the teaching/learning of a foreign language is undeniable, since it contributes to avoid misinterpretation in the communication between sender and recipient. A pragmatic perspective on language teaching is, therefore, essential to study how verbal and non-verbal messages are produced and interpreted in different languages.

\section{The speech act of request}

The theory of speech acts is based on the studies of Austin (1962) that proposed a classification between locutive, illocutionary and perlocutionary acts, a theory that was later reformulated by his disciple Searle (1969). The speech act of making a request belongs to the group of illocutionary directive acts which consist of "attempts [...] by the speaker to get the hearer to do something. They may be very modest 'attempts' as when I invite you to do it or suggest that you do it, or they may be very fierce attempts as I insist that you do it "(Searle, 1976, p.11). Brown \& Levinson (1987, p.65) designate requests as "face-threatening acts", that is, "those acts that by their nature run contrary to the face wants of the addressee and / or the speaker". Since the requests seek to influence the interlocutor, they represent a threat to the negative side of the listener who may consider that request an invasion of their freedom and their right to self-determination. One way to mitigate the request is through conventionally indirect strategies, on the one hand, and not conventionally indirect, on the other. The first case considers strategies that create contextual preconditions through the use of conditional forms (Poderia ajudar-me?), while in the second case the request is partially or totally omitted and replaced by a suggestion that refers to the context in which the communicative interaction occurs (Entramos numa sala e dizemos ao colega que está mesmo ao lado da janela: Aqui está muito quente). According to Blum-Kulka and Olshtain (1989) the speech act of the request may be constituted by the address term, by the head act or by adjuncts (or supporting movements). The alerters serve to capture the attention and guide the interlocutor to what they will ask next. Among the alerters stand out the proper name, titles, appeals, compliments, etc. They may also appear combined in the same act of speech. The head act is part of the sequence that serves to make the request and can vary according to the strategy used or the perspective. The strength of the request can be attenuated or intensified through internal modifiers of the nuclear act, such as courtesy markers (se faz favor), adverbial modifiers of time, mode and quantity (imenso, um pouco), consultative structures (importa-se de), conditional sentences (queria saber se), etc. Finally, the support movements 
have the function of preparing the listener for the request, through mitigators as justifiers or preparers.

\section{Methodology and target group}

The study presented was carried out at the University of Aveiro with a total of 44 students (20 German students and 24 Spanish students) of the 3rd year degree in Languages and Business Studies. The results obtained and analyzed offer data that serve as a basis for the creation of didactic materials and activities to deal with pragmatic aspects in language classes. It is intended that students achieve an appropriate pragmatic competence, which will influence the development of an intercultural communicative competence. To achieve this goal, we subjected students to two types of surveys:a) Discourse Completion Task, which "consists of incomplete discourse sequences that represent socially differentiated situations. Each discourse sequence presents a brief description of the situation, specifying the setting, the social distance between the interlocutors and their status relative to each other, followed by an incomplete dialogue” (Blum-Kulka, \& Olshtain, 1984, p. 198); b) Rating Assessment Test that confronts students with concrete situations in which they have to evaluate communicative interactions in a level scale that goes from not appropriate to appropriate. "The use of scaled-response items for instrument development - is particularly noteworthy because in studies using any kind of data-elicitation format [...] researchers need to know how to respond to the context variables built into the stimulus situations" (Kasper \& Rose, 2002, p. 100). According to Martínez-Flor \& Usó-Juan (2011) this test serves to obtain data for the evaluation of the students' level of pragmatic competence and to activate their pragmatic awareness. Although this type of questionnaire is not as widely used as others, it is a useful tool to complement the DCT, which provides additional information about the students' meta-pragmatic level.

Studies in this area have already addressed the advantages of DCT (Kasper \& Dahl, 1991), which helps to identify essential nuclear situations for the performance of a speech act, as well as to analyze internal and external factors of the communicative context. For our study we chose these two surveys since both are a very useful resource to compare and contrast a concrete act of speech. Despite the fact that both surveys are conducted in writing, which can affect the spontaneity of the discourse, we consider that the information obtained can contribute to identify critical incidents and improve the process of pragmatic awareness of the students. 


\section{Analysis of the corpus}

For this study we used the two types of surveys mentioned above, in which we included communicative situations in different contexts in order to evaluate the students, on the one hand, and to complete the discourse, on the other. Regarding the DCT, our intention was to observe how students perform the speech act of making a request in Portuguese, German and Spanish. In this way, it is possible to observe, among other aspects, the extent to which students are aware of the differences involved in the various linguistic-cultural systems under analysis.

The Rating Assessment Test is for students to evaluate different common everyday situations of the foreign language / culture. The results obtained from this survey constitute a work base for the teacher, since they offer data about the level of students' meta-pragmatic awareness, which together with the DCT allows us to analyze how students value the situations presented. Firstly, we will look at the analysis of the results obtained through the DCT, which included communicative situations in the context of work, on the one hand, and in day-today contexts outside the scope of work, on the other. For the latter case, one of the situations presented consisted of asking for directions to someone unknown in Portuguese. It can be observed that the students preferred the use of elements that attenuated the request (alerters, internal modifiers), so that the request was presented in a more indirect way. All the answers contained alerters like greetings (olá, bom dia, boa tarde, etc.), different ways to get attention (peço desculpa, desculpe, etc.) or the combination of several alerters like (olhe, desculpe; boa tarde, desculpe, etc.).

The nuclear act is carried out from the point of view of the listener and shows deference to the interlocutor when asking him about the commitment to perform the act that is requested (sabe-me dizer, pode dizer-me, poderia indicar-me, etc.). The request is, therefore, made through conventionally indirect structures, namely questions about the preparatory conditions for the performance of the speech act by the listener. The internal structure of the nuclear act is also characterized by the use of syntactic mitigators such as the conditional (poderia, saberia) or the imperfect tense (podia), although it emphasizes a preference for the use of the indicative present, besides attenuators or lexical mitigators as the politeness marker por favor, se fizer favor, etc. At the same time, we found external or support modifiers that refer to the context of the interaction, mitigating the illocutionary force as we can observe in the following examples: Como faço para chegar ao centro da cidade? or Estou perdida e preciso de chegar ao centro da cidade. In the latter case, a justification is used to mitigate the claim. This is an effective mitigation strategy that conveys an attitude of empathy towards the interlocutor indicating the reasons for the request. In another situation the students had to complete a speech act by placing an order in a café. In this context, the productions made were very similar to the previous ones because of the preference for the conventionally indirect way of ordering (Bom dia, queria, por favor, um café e um pão com manteiga; Bom 
dia, queria um café e uma nata, se faz favor). Only on two occasions out of 44 results obtained, the request was made from the listener's point of view, and not from the speaker's, in a more direct way by recourse to the imperative, which emphasizes the illocutionary force, clearly visible in the following example: Boa tarde, dê-me, se faz favor, uma empada e um sumo de laranja. Muito obrigada. To mitigate this most direct request a courtesy marker is used (se faz favor), followed by a mitigator of gratitude. The use of alerts and mitigators conferes a high degree of negative courtesy to the request, since the combination of all these elements aims to reduce a possible conflict between the partners. The students participating in this study also completed the same survey for Spanish and German, respectively. It can be observed that the productions made in the two languages show a similar structure to those made in Portuguese, which reveals a direct transference of the mother tongue. In addition, we can highlight the use of a reduced number of strategies by employing the same alerters as greetings (Buenos días, Guten Tag), attention grabbers (Perdón, Entschuldigung), syntactic mitigators (Podría, Puede, Können/Könnten Sie) and a courtesy marker (por favor, bitte). The request is made in a conventionally indirect manner, thereby attenuating the illocutionary force of the speech act:

Por favor, ¿me puede/podría decir dónde es el centro?; Perdón, por favor, ¿me podría decir por dónde se va al centro?; Guten Tag! Entschuldigung, ich möchte wissen, wo die Universität ist, bitte? Entschuldigung, können/könnten Sie mir sagen, wo die Universität ist?

In the specific context of making a request in a café, in the case of German and Portuguese we observe that the productions show a preference for the use of indirect structures, which does not apply to Spanish. Here we have noticed the use of direct strategies through the expression quiero pedir, realized from the perspective of the speaker being, however, attenuated by the courtesy marker por favor, by an alerter in the form of compliance (Buenas tardes) and also by a mitigator of the force of the request as, for example, muchas gracias: Buenas tardes, quiero pedir una coca-cola y un bocadillo de jamón serrano, por favor, muchas gracias; Buenos días, quiero un bocadillo de jamón serrano y una coca-cola, por favor. Gracias.

In the analysis carried out on the totality of the productions submitted by the students, and taking into account the different situations proposed in the DCT, in which the properties of the communicative contexts vary, it is surprising that despite the advanced level of the Spanish students, the answers given do not change much regarding use of strategies, linguistic structures or forms of treatment. The formal treatment almost always prevails, regardless of the characteristics of the interlocutor. There are, therefore, certain socio-cultural and socio-linguistic difficulties on the part of students which necessarily affect their level of pragmatic competence. 
In a formal context, we presented students with situations in which the social distance between the interlocutors differed, which has direct repercussions on the day-to-day communicative interactions. Two of these situations were to ask a colleague's papers from his or her secretary and ask the boss to leave early. The productions made in German and Spanish were conventionally indirect in both cases and there was no recourse to alternative structures and strategies. By way of example, we can highlight the frequent use of the adverbal modifier imenso (Peço imensa desculpa mas ...) and consultative structures (Importa-se que eu saia mais cedo?, Não te importas de chegar-me esses documentos?), with which the listener's willingness to do something is underlined and the request is mitigated.

Regarding the Rating Assessment Test, the students were confronted with eight different concrete situations regarding the pragmatic variables of status and social distance, among other aspects. The main objective was to issue a value judgment on a scale of 1 (not appropriate) to 5 (appropriate), and on the justification of the student's choice. Two of the communicative contexts that would be less acceptable in German culture but which would have more acceptance in Spanish were the following, translated here into Portuguese: a) Vamos pela rua e alguém nos pára e pergunta o seguinte: "Bom dia, a Avenida xyz?" and b) Estás sentado num café e dizes ao empregado: "um café”!

For both languages, the students considered that the requests submitted to the evaluation were done in a discourteous manner, so they indicated adjectives such as maleducado, rude, desrespeituoso, muito informal in their justification. At the same time, they commented that a correct request should be made using, first and foremost, more alerters to draw attention and guide the speaker to the speech act (Olhe ou desculpe). Participants also indicated that it was necessary to use a lexical mitigator like por favor or se faz favor. The students of the German language were aware that the requests made in the above mentioned contexts are not suitable for the German culture. For the Spanish, they considered that the requests had an imposing and therefore discourteous tone, reason why they classified them as not appropriate. Regarding situations analyzed from the professional context, we observed that the hierarchy plays a fundamental role in the evaluation of what is appropriate or inappropriate. Thus, we noticed that a request made directly using the imperative (quite common in Spanish and less in German), is considered by students a lack of respect in both languages when it comes to an interaction between colleagues (Mário, passa-me essa pasta!), while it is more accepted if a higher hierarchical person makes the request (Marque uma reunião para amanhã!). Still, in the latter case, students commented that it would be more appropriate to make the request in a more conventionally indirect way, through the use of courtesy markers or a combination of various alerts. As for the treatment, we can observe that in the majority the students give preference to the use of the third person and not of the second one. In general, we observed that students transfer their own cultural patterns, namely social and contextual values, which influences the choice of the strategies they consider appropriate to carry out the request. 
Given the way speech acts are performed, they are not universal and vary from language to language, it is evident that in language classes it is important to treat concrete pragmatic aspects, from the intercultural point of view, to avoid interferences that lead to misinterpretations and misconduct during interaction. Thus, it is necessary to familiarize the students, for example, with the most direct way of the Spaniards to use the language. This is also emphasized by Haverkate (1996, p. 51) when he says: "Esta predilección por la expresión directa del mensaje lingüístico se plasma de manera elocuente en el refrán 'Llamar al pan pan y al vino vino". This observation also has its repercussion on the scarce use of the politeness marker por favor and on the fact that the requests made more directly are not considered discourteous in Spanish culture (Bernal, 2006).

\section{Conclusions}

Our interest in the training of speech acts in foreign language classes is due to the fact that an insufficient mastery can lead to critical incidents in intercultural communicative contexts. From our teaching practice, we also learnt that third year students of the degree in Languages and Business Studies still have many difficulties on the pragmatic level. The objective of our study was, therefore, to analyze how the students make a request inside and outside the work context and what they perceived from a concrete act of speech. Given that speech acts are not universal and that there are differences from language to language, it was pertinent to carry out a study for German and Spanish by conducting two surveys that are widely used in pragmatic analyzes: the Discourse Completion Task and the Rating Assessment Test. The results obtained through the analysis of the two tests served to observe to what extent the students' pragmatic awareness is developed and, at the same time, to obtain data on the type of predominant interferences.

We can conclude that the students designed the structures, strategies and perception of the context of their own linguistic-cultural universe for both German and Spanish productions, in a conventionally indirect way. In order to achieve their goal they resorted to only a limited number of strategies that served to alleviate the illocutionary force of the nuclear act. Taking into account that Spanish culture is characterized by positive courtesy, which allows the speaker to reduce the freedom of the listener without the need to use strategies to mitigate the request through, for example, a preparatory question, requests are often made in a more direct way than in Portuguese. In the case of German and Portuguese, where the forms of negative politeness predominate to safeguard the negative social image of the interlocutor, the request is mitigated by the help of several indirect strategies. Finally, we consider it important to carry out studies of this nature, since they provide tools to the teachers that can help them to approach pragmatic contents in the classroom with the intention of developing the students' pragmatic awareness, essential for effective and adequate communication in intercultural contexts. 


\section{References}

Austin, J. L. (1962). How to do things with words. Oxford: Oxford University Press.

Bernal, M. (2006). ¡Ay señor por favor!: usos de por favor que exceden al mandato y a la petición cortés en la conversación española. XVI Congreso de Romanistas Escandinavos, Universidad de Estocolmo.

Blum-Kulka, S. \& Olshtain, E. (1984). Requests and Apologies: A Cross-Cultural Study of Speech Act Realization Patterns (CCSARP). Applied Linguistics, 5 (3), 196-213.

Brown, P. \& Levinson, S. C. (1987). Politeness: Some universals in language usage. Cambridge: Cambridge University Press.

Haverkate, H. (1996). Estrategias de cortesía. Análisis intercultural. In M. A. C. Sánchez \& J. Ramón Heredia (Eds.), Lengua y cultura en la enseñanza del español a extranjeros. Actas del VII Congreso de ASELE, 45-58.

Kasper, G. \& Dahl, M. (1991). Research methods in interlanguage pragmatics. Studies in Second Language Acquisition, 13, 215-247.

Kasper, G. \& Rose, K. R. (2002). Pragmatic development in a second language. Oxford: Blackwell.

Martínez-Flor, A. \& Usó-Juan, E. (2011). Research Methodologies in Pragmatics: Eliciting Refusals to Requests. Estudios de Lingüística Inglesa Aplicada, 11, pp. 47-87.

Searle, J. R. (1969). Speech acts. Cambridge: Cambridge University Press.

Searle, J. R. (1976). The classification of illocutionary acts. Language in Society, 5, 1, 1-24. 